\title{
聴講者応答システムを利用した食の安全講義の効果測定
}

\author{
増田 知尋 ${ }^{1), 2)}$, 村越 环磨 ${ }^{3)}$, 内海 建 $^{2)}$, 木村 敦 ${ }^{4)}$, 日野 明寛 ${ }^{2), 5)}$, 和田 有史 ${ }^{2)}$ \\ ${ }^{1)}$ 文教大学人間科学部 \\ ${ }^{2)}$ 国立研究開発法人農業・食品産業技術総合研究機構 食品総合研究所 \\ ${ }^{3)}$ 千葉大学文学部 \\ 4) 東京電機大学情報環境学部 \\ ${ }^{5)}$ 日本製粉株式会社 日本製粉中央研究所
}

\section{Evaluation of lectures on food safety via an audience response system}

\author{
Tomohiro Masuda ${ }^{1)}{ }^{2)}$, Takuma Murakoshi ${ }^{3)}$, Ken Utsumi ${ }^{2)}$, \\ Atsushi KImura ${ }^{4)}$, Akihiro HinO ${ }^{2), 5)}$, Yuji WADA ${ }^{2)}$ \\ ${ }^{1)}$ Bunkyo University \\ ${ }^{2)}$ National Agriculture and Food Research Organization \\ ${ }^{3)}$ Chiba University \\ ${ }^{4)}$ Tokyo Denki University \\ ${ }^{5)}$ The Central Laboratory, Nippon Flour Mills Co., Ltd.
}

\begin{abstract}
We investigated the feasibility of using an audience response system (ARS) to measure and immediately display the effect of lectures on food safety, related to pesticide residue and radiological substances, on an audience's responses. Students were asked closed questions about typical misperceptions related to food safety, both during and after their lectures. In Experiment 1, 105 students answered six true-or-false questions, including those about pesticide residue and bovine spongiform encephalopathy (BSE). In Experiment 2, 101 students also answered six true-or-false questions, but one question about BSE was replaced by a question about radioactive material. All students responded using an ARS, and the overall true/false rate for each question was displayed to them immediately after each response. The results reveal that the proportion of questions answered correctly was higher after the lecture than during the lecture in both experiments. In addition, the number of participants who answered each question correctly after the lecture was significantly larger than that during the lecture for four of the six questions in both experiments. This study indicates that the effect of a food safety lecture on students understanding is easily measurable using an audience response system.
\end{abstract}

(Received 1 April 2015, Accepted 12 November 2015)

Keywords: risk communication リスク・コミュニケーション, food safety 食の安全, audience response system 聴講者応答システム, residual agricultural chemicals 残留農薬, radioactive substance 放射性物質

\section{1. 緒言}

近年, 食品への残留農薬の問題に加え，大規模な食 中毒被害を発端とする飲食店での牛・豚の肝臓などの 生食用の提供禁止や, 福島の原子力発電所事故に端を

著者連絡先 yujiwd@affrc.go.jp
発する食品に含まれる放射性物質の問題などを背景に, 食の安全に対する消費者の関心が以前にも増して高 まっている，食の安全に関する情報は，マスコミによ る報道やインターネットなど各種メディアを通じて消 費者に提供されているが，それらの情報においては専 門家や生産者の意図が消費者に適切に理解されていな 
いこと，ステークホルダーごとに認識が異なることも 多々ある（朴ら，2014; Honda et al., 2015a; Honda et al., 2015b).

社会を取り巻くリスクに関する情報を行政，専門家， 企業，市民などの関係者間で共有し，相互に意思疎通 を図ることをリスク・コミュニケーションといい,こ のような背景から, カードゲームを用いるなど, 行政 もリスク・コミュニケーションの普及拉よび促進に関 する試みを行っている（例えば，吉川ら，2009）。し かしながら, その効果を測定する方法は確立されてい ない.ここでいう効果とは, リスクの適切な知識と姿 勢, ステークホルダー間のコミュニケーションの促進 であるが, より適切なリスク・コミュニケーション のためには, 消費者にもリスクに関する情報やリス ク低減のための政策・対処行動を獲得し理解する能 力（リスク・リテラシー）が必要である（楠見と上市, 2009 ; 福田, 2012).このようなリスク・リテラシー を育成するための手段の一つに講習会などによる教育 がある（楠見，2013）。講習会などの講義をより意義 のあるものにするためには, 聴講者の理解度を把握し, それに対応させた説明を加えた講義を展開する必要が ある、講義内容の理解度を把握するための簡便な方法 として, ペーパー配布によるアンケートや挙手により 応答を収集する方法もあるが, ペーパーアンケートは 収集・集計に時間がかかるため即時性にそしく，また 挙手による回答は少数意見の場合に挙手しにくいこと や周囲の多数派による影響, あるいは匿名性がないた め自分の知識・意見を周囲の聴講者に知られることに 抵抗がある場合には回答に正確性を欠く可能性がある。

これらの問題点をクリアする, すなわち聴講者の理 解の程度を周囲に知られないようリアルタイムに測 定する方法の一つに, 聴講者応答システム (Audience Response System; ARS）の使用が挙げられる. ARS は パーソナルレスポンスシステム (Personal Response System）とも呼ばれる, 講義者と聴講者の双方向コ ミュニケーションを可能にするツールである. 一般的 なシステムは, 講義者の質問に対して聴講者が個別に 渡されたリモコン（クリッカー）で応答をし，受信機 を接続したパーソナルコンピュー夕（PC）でその応 答を集計するものである. ARS は個別のクリッカー で回答を行うため, 回答がほかの講義者に知られるこ とはなく、またPCを用いた集計のためリアルタイム で集計結果をフィードバックすることができるなど, 即時性も高い.
実際, 講義中にARS を用いた内容理解の効果測定 に対するリアルタイムフィードバックの有用性が示さ れている. 例えば, 兼田と新田（2009）は, 物理学の 授業中に生徒同士の議論を行わせることの効果につい て, 議論前後の質問への回答を ARSによって集計し, 議論後に正答率が向上することを示した。ほかにも， ARS は工学, 数学, 化学, 哲学, 生物学, 物理学医 学や獣医学, 歯学教育, 経済学, 心理学など多くの領 域の教育で用いられている (Caldwell, 2007).

ARS による講義は, 背景の知識や先入観による誤 解を明確にし，解消することもできる (Beatty, 2004). 食の安全に関する知識は, その情報を見ながらであっ ても適切に理解することは難しいこともあり, 加え て提示方法の違いや, 評価者の認知傾向などの要因 によっても理解度が変化する (Honda et al., 2015a; Honda et al., 2015b). また, 知識がある程度あっても, 不適切な判断をしてしまうことも多々ある。これに関 連する最近の話題として, 平成 24 年 7 月に食中毒の リスクが高いことから牛の肝臓を生食用として販売・ 提供することが禁止された直後, 豚のレバーを代用と して提供する飲食店が増加したことが挙げられる。 そ の後, 平成 27 年 6 月に $\mathrm{E}$ 型肝炎ウィルスの感染リス クや食中毒のリスクにより, 豚肉や豚の内臓を生食用 として販売・提供することが禁止された。 しかし, 豚 の肉や内臓の生食リスクが高く, 避けるべきであるこ とは, 以前からの常識であった，牛レバーの生食が禁 止されたことにより, 公衆衛生学などの講習を受けた 食品衛生責任者でさえ, “禁止されていない豚の生レ バーは合法”, “すなわち提供しても問題がない”, と いうヒューリスティックスによって, 豚の生レバーを 提供する判断を下してしまったのであろう。客側にも “飲食店で提供されるものは食べられる”というヒュー リスティックスがあり, 両者に打いて, 常識を破る行 動に至らしめている.

ARS を用いることで, 食の安全に関する知識や情 報のように, 知っていても適切な意思決定がなされて いない可能性があっても, 簡便かつ正確に聴講者の理 解の状況を確認することができれば, 適切な解説を付 加し, より効果的な講義を展開することが可能とな る. 一方で, このような情報の受け取り手の感じ方が 判断に関係する講義について, 理解度や講義の効果を ARS によって測定した事例は見当たらない. そこで, 本実験では, 食の安全に関する講義において, 聴講者 の回答を収集・集計・提示できる ARS を用いて, 知 
識の有無が正解・不正解と直結している問題ではなく， 情報の捉え方・感じ方が判断に関係すると考えられる 問題について, 理解度の測定を簡便に行うことを試み た.

\section{2. 実験 1}

食の安全に関する講義において, ARS を用いて講 義の効果が測定可能かどうかを検討した。

\section{2-1. 実験方法}

\section{1）実験参加者}

実験参加者は国内の国立大学に在籍する農学専攻の 大学生および大学院生の計 105 人であった. 本研究の 実施については, ヘルシンキ宣言に準拠し, (独) 農研 機構食品総合研究所の人間を対象とする生物医学的研 究に関する倫理委員会の審査の承認を得た.

\section{2) 材料}

計 6 問の問題を講義中に出題した。実験で用いた質 問を Table 1 に示した. 質問は教科書的な知識だけで はなく, 日常的な食行動における意思決定にかかわる 判断を促すように作成した。それぞれの質問は, 食品 のリスク (Q1), BSE（Q2），残留農薬（Q3），合成保 存料 (Q4), 遺伝子組換え（Q5）, 肉の生食（Q6）に 関する内容であった。すべての質問は「はい」か「い いえ」いずれかの 2 肢強制選択により回答した。

\section{3）手続き}

実験は二つの大学で 2010 年 8 月と 10 月のそれぞれ 1 日の講義中に行った. 講義前にクリッカー（Interwrite Learning 社 Interwrite Cricket）を各実験参加者に配布し， その使用方法を説明した. 講義は Microsoft PowerPoint を用いて行い, クリッカーにより回答するための質問 は講義中のスライドに挿入されていた，各質問は講義 中でのそれぞれの関連トピックの前に呈示され, クリッ カーを用いて Yes/No で回答をするよう求められた。
全員の回答を確認後, 各回答の割合を棒グラフで呈示 した.このことにより, 本講義に参加している実験参 加者全体の回答割合のフィードバックを行った．また， 講義による理解度の変化を検討するため, 講義終了 後に同様の方法で講義中に行った計 6 問の質問に ARS を用いて回答した (Figure 1). 各質問間の講義は 10〜 20 分程度であった.

なお，講義中にはそれぞれの質問の正答は伝えず, 講義後にもう一度同様の質問を出題することも伝えな かった。

\section{4) 解析方法}

1）個人内の正答率の変化として, 講義中および講 義後それぞれで全 6 問中での正答率を個人ごとに算出 し, 正答率の変化について $t$ 検定を行った. 2) 質問 項目ごとの正答者数の変化として, 各質問項目で講義

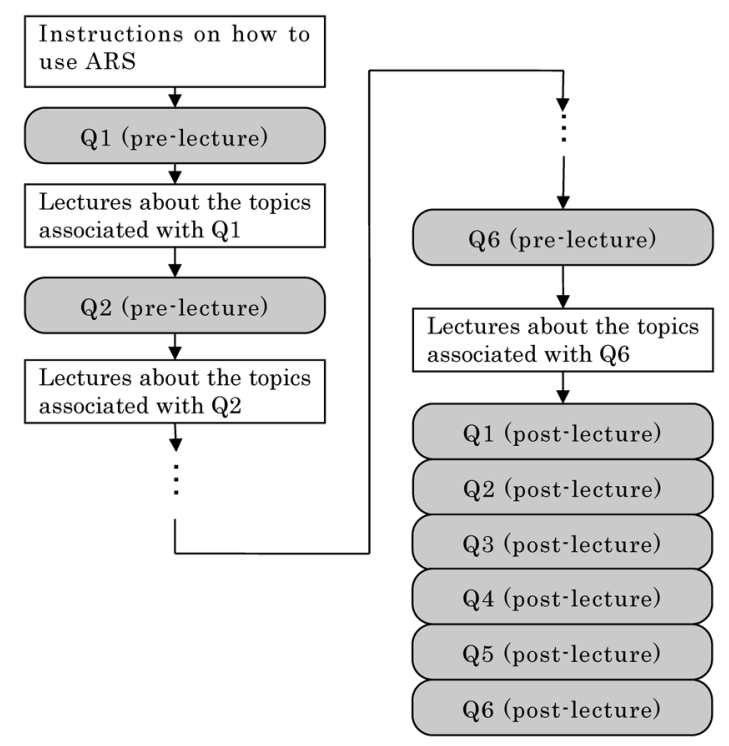

Figure 1 Flowchart for the entire experimental procedure

Table 1 Six questions about food safety used in Experiment 1

\begin{tabular}{|c|c|c|}
\hline 質問番号 & 領域（トピック） & 質問項目 \\
\hline Q1 & 食品のリスク & リスク 0（ゼロ）の食品以外は食べるべきではない. \\
\hline Q2 & BSE & 若い牛についても全頭検査すれば, BSE のリスクは低減する？ \\
\hline Q3 & 残留農薬 & 国内で流通している野菜は, 健康被害を与えるほどの残留農薬を含むものが多い. \\
\hline Q4 & 合成保存料 & $\begin{array}{l}\text { 合成保存料や合成着色料が使われている加工食品を食べていると, 健康被害にあ } \\
\text { うリスクが高まる. }\end{array}$ \\
\hline Q5 & 遺伝子組換え & 遺伝子組換えは古来の生態系の破壊やヒトの健康被害を生じさせる技術である。 \\
\hline Q6 & 肉の生食 & ちゃんとした店でだされる生の牛肉ならば, 食べても食中毒にはならない. \\
\hline
\end{tabular}


中および講義後それぞれの正答者数をカウントし, 質 問項目ごとに McNemarの検定を行った.

\section{2-2. 実験結果}

講義前後での正答率について, 全実験参加者の平均 值を Figure 2 に示した，正答率を従属変数とした講義 前後での $t$ 検定の結果, 有意差が認められた $(t(104)=$ $11.13, p<0.001)$.

質問項目ごとに講義前後での正答者数を算出し (Figure 3), 連続性の補正を行った McNemar 検定の結 果, Q2, Q3，Q4，Q6で講義前後の正答者数にそれぞれ 有意差が認められた $\left(\chi^{2}(1)=52.02, p<0.001 ; \chi^{2}(1)=\right.$ $4.00, p=0.046 ; \chi^{2}(1)=32.65, p<0.001 ; \chi^{2}(1)=9.33, p=$ $0.002)$.

これらの結果から, ARS による各トピックに関連 する質問への回答に関して, 講義後の正答率は講義前 に比べて高く, また BSE (Q2), 残留農薬 (Q3), 合 成保存料 (Q4), 肉の生食（Q6）に関する質問では講 義後に正答者数が増加することが示された.

\section{2-3. 考察}

講義後の質問への正答率が講義前より高くなった. このことは, 食の安全に関する問題のように, 知識と して知っているだけでは適切に回答をすることが難し いと考えられる事例において, 講義中の理解の変化を リアルタイムに測定することができたことを示してい る.

また, 各質問での正答者数の変化に関して, 食のリ スクに関する質問（Q1）に関しては講義前後の正答 者数に有意な差はなかったが, 講義前の正答者数が多 かったことによる天井効果であると考えられる。一方 で，遺伝子組換えに関する質問（Q5）において，講 義前の正答者数が Q1 ほど多くなかったにもかかわら ず，正答者数の有意な増加が見られなかったことにつ

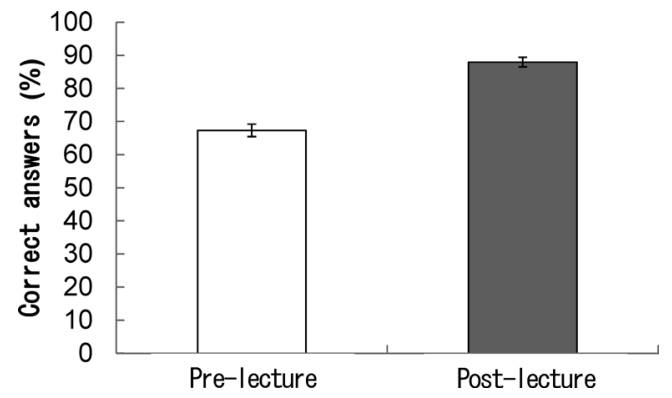

Figure 2 The mean ratings of correct answers in preand post-lecture (Error bars indicate standard errors; $N=105$ )
いては, 適切な理解を促すために講義内容あるいは教 材を修正する必要があると考えられる。

ARS を用いて理解度を講義中に把握することが できれば, Q1 や Q5 と関連する講義に拈いて, 鈴木 ら（2008）がリアルタイムフィードバックの利点とし ている, 講義中の口頭での補足や説明の程度を講義者 が調整することが可能になると考えられる. ペーパー によるアンケートやテストであっても, 講義前後の成 績を比較することは可能であるが, ARS を用いるこ とで大人数が参加している講義であっても即座に集計 ができ, 講義中にフィードバックを行うことができる ことから, 講義の効果測定, あるいはより適切な講義 展開のために ARS を用いることは有用であると考え られる。

\section{3. 実験 2}

2011 年 3 月の震災以降, 暫定規制值や 2012 年 4 月 からの新たな基準值の設定をはじめとして食と放射性 物質に関する報道が多く行われた，そこで実験 2 では, 実験 1 の講義内容に食と放射性物質に関する講義を追 加し, 実験 1 と同様にARS を用いた講義の効果測定 を行った.

\section{3-1. 実験方法}

\section{1）実験参加者}

実験参加者は, 国内の農学系の大学に在籍する大学 生と大学院生の計 101 人であった. 実験 1 に参加した 学生は含まれていない.

本研究の実施については, ヘルシンキ宣言に準拠し, (独) 農研機構食品総合研究所の人間を対象とする生物 医学的研究に関する倫理委員会の審査の承認を得た。

\section{2) 材料}

実験 1 と同様に, 計 6 問の質問を講義中に出題した.

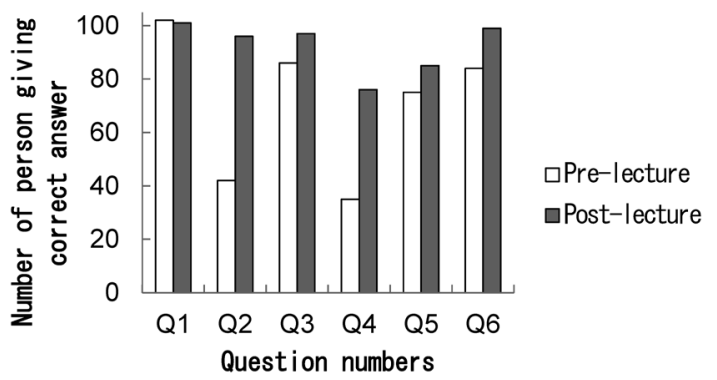

Figure 3 Total number of people who answered correctly in each question in the pre- and post-lectures 
実験で用いた質問を Table 2 に示した. それぞれの質問 は, 食品のリスク $(\mathrm{Q} 1)$, 残留農薬 (Q2), 放射線 (Q3), 合成保存料 (Q4), 遺伝子組換え (Q5), 肉の生食 (Q6) に関する内容であった，Q1 および Q4〜6 は実験 1 と 同様の質問を用いた。 また，Q2 は実験 1 における Q3 (残留農薬）の質問を用い，Q3 には放射線に関する質 問項目を加えた. また，Q4 および Q6 は質問の意図 を明確にするために表現に小変更を加えた.

すべての質問は実験 1 と同様に「はい」か「いいえ」 いずれかの 2 肢強制選択により回答した。

\section{3）手続き}

実験は 2 大学で 2012 年 7 月と 8 月のそれぞれ 1 日 の講義中に行った. 方法は実験 1 と同様で, それぞれ の関連トピックの前に質問を行い, 講義終了後に同様 の計 6 問の質問を行った.

\section{4) 解析方法}

実験 1 と同様であった.

\section{3-2. 実験結果}

実験 1 と同様に, 講義中および講義後での正答率 について, 全実験参加者の平均值を Figure 4 に示した。 正答率を従属変数とした $t$ 検定の結果, 講義前後の正 答率に有意差が認められた $(t(100)=9.61, p<0.001)$.

質問ごとに講義中および講義後に行った問題の正 答者数を算出し (Figure 5), 連続性の補正を行った McNemar 検定の結果, Q1, Q3, Q4, Q5 で正答者数に それぞれ有意差が認められた $\left(\chi^{2}(1)=4.90, p=0.027\right.$; $\chi^{2}(1)=12.96, p<0.001 ; \chi^{2}(1)=29.64, p<0.001 ; \chi^{2}(1)=$ $14.45, p<0.001)$.

これらの結果から, ARSによる質問への回答に関 して, 講義後の正答率は講義中の関連トピック前のそ れよりも高く，また食品のリスク (Q1)，放射線（Q3）， 合成保存料（Q4），遺伝子組換え（Q5）に関する質問
では講義後に正答者数が増加することが示された.

\section{3-3. 考察}

実験 1 と同様に, 講義後の正答率が高くなった. こ のことは, 食の安全に関する問題のように, 知識とし て知っているだけでは適切に回答をすることが難しい と考えられる事例において, 講義中の理解の変化をリ アルタイムに測定することができたことを示している.

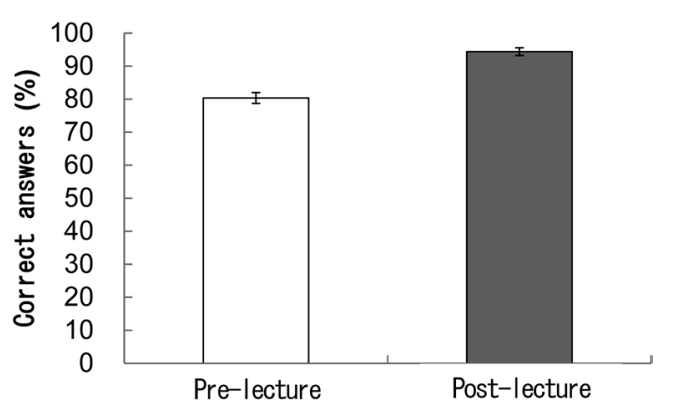

Figure 4 The Mean ratings of correct answers in preand post-lecture

(Error bars indicate standard errors; $N=101$ )

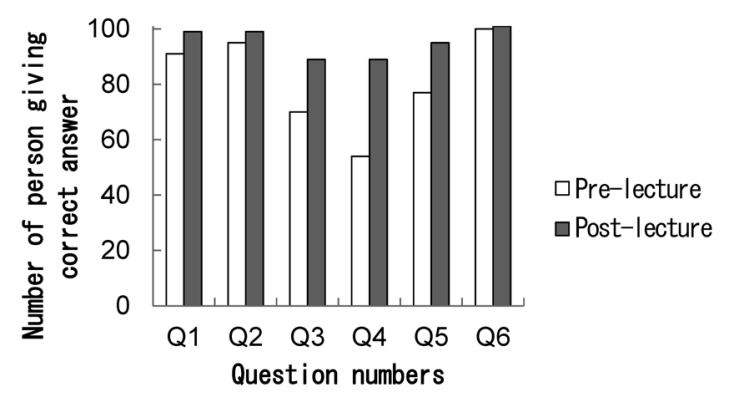

Figure 5 Total number of people who answered correctly in each question in the pre- and post-lectures

Table 2 Six questions about food safety used in Experiment 2

\begin{tabular}{|c|c|c|}
\hline 質問番号 & 領域（トピック） & 質問項目 \\
\hline Q1 & 食品のリスク & リスク０（ゼロ）の食品以外は食べるべきではない. \\
\hline Q2 & 残留農薬 & 国内で流通している野菜は, 健康被害を与えるほどの残留農薬を含むものが多い. \\
\hline Q3 & 放射線 & $\begin{array}{c}\text { 現在の「放射線についての暫定規制値」を超えた食品を食べると, 将来ガンにな } \\
\text { る可能性が高くなることがわかっつて }\end{array}$ \\
\hline Q4 & 合成保存料 & $\begin{array}{l}\text { 保存料や合成着色料が使われている加工食品を食べていると，健康被害にあうリ } \\
\text { スクが高まる. }\end{array}$ \\
\hline Q5 & 遺伝子組換え & 遺伝子組換えは古来の生態系の破壊やヒトの健康被害を生じさせる技術である。 \\
\hline Q6 & 肉の生食 & レストランでだされる肉ならば, 生やたたきで食べても食中毒にはならない. \\
\hline
\end{tabular}


加えて, 実験 2 で新たに加えた放射線に関する質 問（Q3）に関しても，講義の効果を ARSによって測 定できることが示された。一方で, 実験 1 では残留農 薬（実験 1 の Q3, 実験 2 の Q2) および肉の生食 (Q6) に関する質問で講義後に正答者数が増加したが, 実 験 2 では有意な増加は見られなかった。このことは, 実験 2 ではどちらの質問も講義前の正答率が高かった ことによる天井効果によるものと考えられる.

また, 肉の生食 (Q6) に関しては, 平成 23 年 (2011年) に発生した焼き肉チェーン店の集団食中毒事件や平 成 24 年（2012 年） 7 月から食品安全基本法第 11 条 第 1 項第 2 号に基づいて飲食店での牛の肝臓を生食用 として提供することが禁止されたことなどにより，生 肉と食中毒の関係に関する感心が高まっていたために, 事前に適切な理解をしている参加者が多かったためと 考えられる.

\section{4. 総合考察}

本実験では, 講義中および講義後に出題する食の安 全に関連した質問について ARS を用いて回答を行わ せ，実験参加者ごとの計 6 問の正答率および質問ごと での正答者数の変化から食の安全に関する講義の効果 の測定を試みた。

その結果, 二つの実験どちらでも, それぞれのト ピックの講義前に行った全 6 問の正答率に比べ, 講義 後に行った同様の 6 問の正答率が増加した。 また, そ れぞれのトピックの講義をする前に行った質問の正答 者数が少なかった項目に関しては講義後に正答者数が 増加することが示された。このことは, ARS を用い た回答により，食の安全に関する講義の効果が簡便か つ即座に測定できることを示している.

加えて, ARS を用いることで, 関連トピックの講 義をする前の, それらに関する聴講者の知識の程度を 知ることができる。例えば，実験 1 における Q1（食 品のリスク), 実験 2 の $\mathrm{Q} 2$ (残留農薬), Q6 (肉の生食) のように講義前から正答率が高いトピックは, あらか じめ参加者が関連する知識を持っていて適切な理解を していると考えられる。

また, 実験 1 の Q5（遺伝子組換え）のように, 講 義前での正答率が高くなかったにもかかわらず，講義 後の正答率が統計的に有意に高くならなかったトピッ クでは, 適切な理解を促進するための講義内容の改善 や情報の追加などを行うことが必要になると考えられ る. 加えて, 実験 1 の Q3 および実験 2 のQ2 は同じ
残留農薬に関する質問だが, 講義後での正答者数の有 意な増加が見られたのは実験 1 のみであった，同様に， Q5（遺伝子組換え）の質問は, 実験 2 でのみ正答者 数が有意に増加した. これらのことは, 講義を行う参 加者群ごとに事前の知識が異なっていた可能性がある が, ARS を用いることで, このような群間での差異 までをも即座に検出することができる.

このように, 講義ごとに, 適切な理解がなされてい るトピックと理解がなされていないトピックを知るこ とができ, 加えて, 講義による効果が大きくなかっ たトピックを即座に把握することができるため, ARS を用いることが, 聴講者にとってより有効な講義を展 開するための一助となる可能性がある.

また, ARS 利用の利点は, 聴講者の理解の程度お よび講義の効果を把握するだけではなく, 通常形式 の講義に比べて理解度そのものが向上することにも ある. ARS を用いた講義中の応答は, 効果的な講義 形式の一つと考えられている双方向型（interactive engagement）講義に該当する. 双方向型講義とは, 講 義中にワークショップ形式や学生間の議論を行うな ど, 話を聴く側に発言や回答を求める機会を設ける形 式を指す. Hake（1998）は, 物理学の基本概念を理 解する講義の前後にテストを行い, 双方向型講義が 従来の講義形式より成績向上が大きいことを示した。 また, 大学の講義でARS を用いた報告によると, 成 績優秀者の増加と低成績者の減少がみられたという (Caldwell, 2007). 同様に, 講義中に ARS を用いて質 問に答える群, 印刷物で質問に答える群, 質問を出 さない統制群で中間テストの成績を比較すると, ARS 群はその他の群よりも正答率が高くなることが示され ている (Mayer et al., 2009).

さらに, ARS を用いた生物学の講義では, 出席率 が 20\%程向上したとの報告もある（Caldwell, 2007）.

近年, 国内大学においても, 物理学などの講義で ARS を導入するための試みがなされており（鈴木ら， 2006 ; 鈴木ら, 2008), 学生は全般的に ARS を用いた 講義にポジティブな印象を持っていることが明らかと なっている（猫田, 2012).

このように, インタラクション・ッールの利用は, 講義者側が聴講者の理解度を把握するだけではなく, 聴講者が講義内容をより効果的に理解することができ る. 加えて, 本実験では食の安全に関して, インタラ クション・ッールの一つである ARS を用いた講義の 効果測定に焦点を当てたが, 本実験で用いた講義内容 
は, 先行研究で対象とされてきた工学や物理学の講義 とは異なり, 知識の有無が正解・不正解に直結するも のではなく, 食の安全に関する知識の受け取り方や解 釈の仕方が回答に影響を及ぼす可能性が高い。例えば, 本研究での調査対象は農学を専門とする大学生と大学 院生であり, 遺伝子組換えや食品関係全般についての 基礎知識を一般の消費者よりも高いレベルで有してい たはずだが, 食の安全の視点から行われた講義によっ て, 態度の変容が見られた。 そのため, 効果の測定の みならず，食の安全に関する報道内容のより適切な理 解とそれらの情報に関する適切な姿勢を促進するため の効果的な講義が可能になると考えられる. また, イ ンタラクション・ツールを用いた回答割合のフィード バックは, 講義前後のクラス全体としての理解度の向 上を受講生が知ることができるため, 受講満足度が向 上する可能性もある. 今後, フィードバックの有無そ のものが受講満足度や理解度の向上にどの程度影響を 及ぼすのか, 検討を行う必要がある.

Honda et al. (2015b) は, 残留農薬基準値を題材と して, 食の安全やリスクに関する情報は, 文字やグラ フを用いて提示するだけでは大多数が内容を適切に理 解することは難しく, 特に認知的努力が必要となるグ ラフによる説明では適切な情報の理解は困難であるこ と, また, それら食品の安全性に関する判断は, 消費 者の認知傾向などの要因で変化することを指摘してい る.このような, 知識を知るだけでは単純に適切な判 断を行うことができない問題であっても, ARS を用 いて, 理解の程度や誤解の有無を確認しながら講義を 行うことで，より質の高いリスク・リテラシーを簡便 に身につけることができ，より適切なリスク・コミュ ニケーションが行われていくことが期待される.

\section{謝 辞}

本研究の実施にあたり, 厚生労働科学研究費補助金 （課題番号：H24-食品-若手-016）の支援を受けた.

\section{利益相反}

利益相反に相当する事項はない.

\section{引用文献}

Beatty, I.D. (2004) Transforming student learning with classroom communication systems, Research Bulletin ERB0403, Educause Center for Applied Research 2004.
Caldwell, J.E. (2007) Clickers in the large classroom: Current research and best-practice tips, Life Sciences Education, 6(1), 9-20.

福田 充（2012） マスメディアのリスク情報とオー ディエンスの受容, 『リスクの社会心理学一人間 の理解と信頼の構築に向けて一』, 中谷内一也編, 有斐閣, 東京, pp. 155-174.

Hake, R.R. (1998) Interactive-engagement versus traditional methods: A six-thousand-student survey of mechanics test data for introductory physics courses, American Journal of Physics, 66(1), 64-74.

Honda, H., Ogawa, M., Murakoshi, T., Masuda, T., Utsumi, K., Nei, D. and Wada, Y. (2015a) Variation in risk judgment on radiation contamination of food: Thinking trait and profession, Food Quality and Preference, 46, 119-125.

Honda, H., Ogawa, M., Murakoshi, T., Masuda, T., Utsumi, K., Park, S., Kimura, A., Nei, D. and Wada, Y. (2015b) Effect of visual aids and individual differences of cognitive traits in judgments on food safety, Food Policy, 55, 33-40.

兼田真之, 新田英雄（2009）クリッカーを用いたピ ア・インストラクションの授業実践, 物理教育, 57 (2), 103-107.

楠見 孝 (2013) 科学リテラシーとリスクリテラシー, 日本リスク研究学会誌, 23(1), 29-36.

楠見 孝, 上市秀雄 (2009) 人は健康リスクをどの ようにみているか, 『健康リスク・コミュニケー ションの手引き』, 吉川肇子編著, ナカニシヤ出 版, pp. 96-115.

Mayer, R.E., Stull, A., DeLeeuw, K., Almeroth, K., Bimber, B., Chun, D., Bulger, M., Campbell, J., Knight, A. and Zhang, H. (2009) Clickers in college classrooms: Fostering learning with questioning methods in large lecture classes, Contemporary Educational Psychology, 34(1), 51-57.

猫田泰敏（2012）疫学講義に打けるクリッカーの使 用と学生の反応, 日本看護研究学会雑誌, $35(1)$, 137-143.

朴 ソラ, 増田知尋, 村越环磨, 川嵪弥生, 内海 建, 木村敦, 小山慎一, 日比野治雄, 日野明寬, 和田有史（2014）イラストを用いた食品中の残 留農薬量の理解度の検討, 日本健康教育学会誌, $22(2), 100-110$.

鈴木久男, 細川敏幸, 山田邦雅, 前田展希, 小野寺 
聴講者応答システムを利用した食の安全講義の効果測定

彰（2006）初等物理教育における能動的学習シ ステムの構築, 北海道大学高等教育ジャーナル, 14, 89-97.

鈴木久男, 武貞正樹, 引原俊哉, 山田邦雅, 小野寺 彰（2008）授業応答システム“クリッカー”によ る能動的学習授業一北大物理教育での 1 年間の
実践報告一，高等教育ジャーナル一高等教育と 生涯学習一, 16, 1-17.

吉川肇子, 矢守克也, 杉浦淳吉（2009）『クロスロー ド・ネクスト一続: ゲームで学ぶリスク・コミュ ニケーション一』, ナカニシヤ出版, 京都. 